\section{New Year Honours List}

The names of the following men of science and others associated with scientific work appear in the New Year Honours List :

O.M. : Field Marshal J. C. Smuts.

Hon. O.M. : Mr. John Winant.

Viscount: The Right Hon. S. M. Bruce, chairman of the International Emergency Food Council.

Baron : Sir Ernest Simon, for public services.

G.C.B. : Sir Alan Barlow, second secretary, H.M. Treasury.

K.C.V.O.: Evelyn C. Shaw, secretary to the Commissioners of the Exhibition of $\mathbf{1 8 5 1 .}$

Knights : Major G. St. J. Orde Browne, labour adviser, Colonial Office; Major-General H. C. Buckley, formerly principal of the Medical College, Agra; Dr. W.H. Coates, a deputy-chairman of I.C.I., Ltd., for services to Government departments; Prof. Kerr Grant, professor of physics in the University of Adelaide, for public services ; Prof. W. N. Haworth, Mason professor of chemistry and director of the Chemistry Department, University of Birmingham; Prof. C. E. Hercus, professor of bacteriology and preventive medicine and dean of the Medical School, University of Otago ; Dr. E. W. Smith, lately president of the Institute of Fuel; R. Thomas, agricultural adviser to the Government of Sind, and managing director of Sind Land Development.

C.B. : Air Commodore F. Whittle.

C.M.G. : Prof. P. A. Buxton, professor of entomology in the University of London and director of the Dəpartment of Entomology, London School of Hygiene and Tropical Medicine; A. D. Storke, for services in connexion with mineral resources in the Colonial Empire.

C.I.E.: A. P. F. Hamilton, inspector-general of forests, India; Colonel O. Slater, director of the Survey of India; Lieut.-Colonel W. J. Webster, senior assistant director, Central Research Institute, Kasauli.

C.B.E.: Prof. F. T. Brooks, professor of botany in the University of Cambridge; O. V. Guy, secretary of the Cambridge University Appointments Board; Prof. T. D. Jones, professor of mining in the University of Wales, and director of the Mining Research Laboratory, University College, Cardiff; Dr. F. C. Toy, director of the British Cotton Industry Research Association ; Prof. T. Wallace, director of the Bristol University Agricultural and Horticultural Research Station, Long Ashton.

\section{Indian Science Congress Association}

THe Indian Science Congress Association is meeting in Delhi during January 2-8 under the presidency of Pandit Jawaharlal Nehru. The general theme of the meoting is research and national planning. The executive committee of the Association has taken an initiative among Associations for the Advancement of Science in planning to make its annual meetings international occasions; strong delegations of men of science from a number of countries will attend the meeting at Delhi, and some will remain in India for a number of weeks visiting centres of individual interest, lecturing and advising. The British delegation, appointed by the Royal Society and the British
Association, includes Prof. P. M. S. Blackett, Prof. W. Brown, Sir Charles Darwin, Sir Arthur Fleming, Prof. H. Munro Fox, Sir Harold Spencer Jones, Prof. L. J. Mordell, Prof. L. Dudley Stamp and Sir D'Arcy Thompson. The British party travelled from London Airport in company with the delegations from Canada, the United States and France.

\section{Charles L. Mayer Award: Dr. C. Jayaratnam Eliezer}

A Chartes L. Mayer Award of 2,000 dollars, offered by the National Science Fund of the U.S. National Academy of Sciences for an essay on the nature of light, has been allocated to Dr. C. Jayaratnam Eliezer, for a paper on "The Interaction of Particles and an Electromagnetic Field". Dr. Eliezer, who is twenty-eight years old, is a native of Ceylon. After a distinguished career at the Ceylon University College, he entered Christ's College, Cambridge, and read for the Mathematical Tripos. He began research studies in quantum mechanics under the supervision of Prof. P. A. M. Dirac, and won an Isaac Newton Studentship and a Smith's Prize. During 1943-46 he was lecturing at the University of Ceylon, returning to Cambridge in 1946 as a research fellow of Christ's College. A second Charles L. Mayer Award was offered but was not awarded, no other essay received being considered suitable.

\section{Sir Ben Lockspeiser}

As announced in Nature of December 14, p. 867, Sir Ben Lockspeiser has been appointed chief scientist to the Ministry of Supply. Sir Ben, who is fifty-five, was at Sidney Sussex College, Cambridge. During the First World War he served in Gallipoli and Egypt. He afterwards worked at the Admiralty's Laboratory at Sheffield, and was for a time in the Inventions Department of the Ministry of Munitions. $\mathrm{He}$ joined the Royal Aircraft Establishment in 1921. His first work was to assist Dr. A. A. Griffith in investigations on phase complexity and on stress concentration in plastic crystals. $\mathrm{He}$ turned his attention, at the R.A.E., to a variety of aeronautical problems, such as wing flutter, instrument design, the design of windscreens and the prevention of ice accretion. Sir Ben was responsible, with Dr. Ramsbottom, for the development of the early form of ehemical anti-icing device consisting of a porous wing nose-piece kept saturated with ethylene glycol, afterwards manufactured by the Dunlop Rubber Co. In 1936 he transferred to the Air Defence Department of the Royal Aircraft Establishment, where he was closely concerned with the development of the balloon barrage in the form in which it played an important part in defence during the Second World War, his work including theoretical aspects of the interception problem, practical trials and the effect of the employ. ment of the barrage on aircraft design.

In 1939, Sir Ben moved to Air Ministry headquarters as assistant director of scientific research. In the Ministry of Aircraft Production he became in 1941 deputy director with responsibility for research on armaments, including fuses and aerial mine barrage schemes. He succeeded Dr. D. R. Pye as director of scientific research in 1943, and was made a director-general in 1945 . $\mathrm{He}$ was knighted in January 1946 . 